\title{
Derek Walcott's Dream on Monkey Mountain: A Multifaceted Phantasmagorical Narrative
}

\author{
Zohreh Ramin \\ Department of English, University of Tehran, Tehran, Iran \\ Monireh Arvin \\ Department of English, Alborz Campus, University of Tehran, Alborz, Iran
}

\begin{abstract}
When identifying different strands of criticism on Derek Walcott's play, Dream on Monkey Mountain (1970), one is pleasantly surprised by the scope of theoretical approaches towards his dramatic work. Almost every critical school of literary theory can be found in the writings on Walcott's play. This diversity in form is paralleled by an even greater variety of content, making it all but impossible to tag Walcott's drama with a single label. Most critics concur that Dream on Monkey Mountain is a complex play, full of complicated, sometimes, contradictory images and metaphors. Dangling between dreams and reality, Walcott's play, according to the author of this paper, is a multifaceted narrative. Focusing only on the concept of "dream", the present article, appreciating and reflecting some of the significant relevant interpretations (all about dreams), tends to add that the identity, thus destiny, of a (colonised) nation is shaped also by their collective unconscious shared in the psychic inheritance of all members of the human family.
\end{abstract}

Index Terms - archetype, Caribbean identity, collective unconscious, double-consciousness, dream play

\section{INTRODUCTION}

Living in mixed St. Lucian world and exposed to both colonial and folk cultures, Derek Walcott is aware of the plurality of Caribbean society. Exploring European colonial heritage of the Caribbean, Walcott tries to find expressions for the difficulties inherent in Caribbean identity, a key theme that runs throughout his works. Walcott's works are typically postcolonial in that they acknowledge the combination of European and African heritages that have influenced the development of identity in the Caribbean.

Dream on Monkey Mountain is Walcott's best known and most performed play. It was first performed in 1967, at the Central Library Theatre in Toronto, Canada. The play made its New York City first appearance in 1971, at St. Mark's Playhouse. This production gained Walcott an Obie Award. Frequently performed since its commencement, it is a complex allegory, which at its heart, concerns racial and cultural identity. In Dream on Monkey Mountain, as Nasser Dasht Peyma in "Ref. [9]" argues "Walcott changes the folk form into a complex, poetic proposal of the psychology of cultural subjugation and the desire for freedom" (2009, p. 157).

The form of the play depends deeply on ritual, symbolic, and archetypal elements, which are dependent on masquerade, music, and mime for their effect. The play opens with a mime in which movement, dance and song are combined to introduce its main themes. The mime gives way to a lament sung by a story-teller and chorus, introducing Makak (the play's main character) to the reader. Therefore, even before the narrative action commences, the drama is located in an oral folk context. Since "the play is a dream," put by Walcott himself, it would be considered through various approaches. More significantly, Dream on Monkey Mountain, according to the author of this paper, could be read once more under the light of some of the common conceptions of Jungian Psychology in the form of its archetypal insights to confirm the play's best artistic expression in the face of colonisation.

\section{LITERATURE REVIEW}

Kelly Baker Josephs in his article, "Ref. [3]", asserts that the play is a fantasy based on the hallucination of an old woodcutter who has a vision of returning to Africa. In Dream on Monkey Mountain Walcott's mosaic of folklore connected by fantasy creates space for the newness that will allow for the psychological and material "shaping" of a Caribbean community. Walcott organises the folkloric elements within the hallucinations of the play's protagonist, Makak, allowing dreams and madness to create the glue that produces a cohesive Caribbeanness within the play (2010, p. 2).

Similarly, Patrick Colm Hogan in his article, "Ref. [2]", argues that establishing both a social and a personal identity which are not determined by the oppressor has been a recurrent theme of subaltern writers, from postcolonials, to women, to racial and ethnic minorities. A number of writers have chosen to look at this issue from the other side, "examining the ways in which oppressive ideologies undermine personal identity and even lead to madness" (2000, p. 103). Colm Hogan believes that the delirium from which Makak suffers is clearly connected with his inability to link 
himself to family or culture. He has, in effect, been formed by an ideology which strips him of the individual and human identity implicit in the name and which seeks to structure his personal identity "around a racial typology according to which black is to white as monkey is to human" (2000, p. 107). Colm Hogan concludes that Walcott's play presents us with a powerful literary analysis of the constitution of colonial identity, its varieties and development, responding to the far more important issues of social and personal identity in the real world.

However, Robert Fox and Lloyd Brown, “although taking different approaches, both underscore the play's dream element and metaphoric dimension." Brown illustrates that the play is "revolutionary" and combines "symbolism with fantasy." In spite of its Eurocentric style, Brown argues, "Walcott's play insists instead on the transcultural unity of black American and Caribbean experience." Fox in turn emphasises the "mythological aspect of Walcott's drama," arguing that the play goes "beyond redeeming the downtrodden to dramatise the disparities between a consciousness that is creative and metaphoric, and one that is straightforward and imprisoning" (Haney, 2005, p. 82).

Despite their insightful interpretations, all about dreams, these scholars have overlooked a significant aspect of psychoanalysis: the relationship between dreams and identity in the face of colonisation. An investigation into their relationship from the perspective of the Jungian psychology will deepen our understanding of the orchestrating function of the collective unconscious and, more important, Derek Walcott's philosophical reflections on racial memory, dreams, and archetypes. This essay, appreciating and incorporating some of the aforementioned overlapping interpretations, tends to assert that the identity, thus destiny, of a (colonised) nation is shaped also by their collective unconscious shared in the psychic inheritance of all members of the human family.

\section{DISCUSSION}

\section{A. Dream on Monkey Mountain: A 'Dream Play'}

"Dream on Monkey Mountain," as Nasser Dasht Peyma argues, "belongs to the $20^{\text {th }}$ century genre called 'Dream Plays', connected with works by playwrights such as the Swedish playwright August Strindberg” (2009, p. 157). In Derek Walcott's own words, "the play is a dream, one that exists as much in the given minds of its principal characters as in that of its writer" (Walcott, Dream, 1970, p. 290). It seems, like a dream, the play resists description and interpretation, and it can mean different things to different readers. Makak, the principal character in the play, lives in Monkey Mountain, which is depicted in the prologue as "volcanic". A volcano, signifying Makak himself, is unpredictable, sleeping violence, submerged energies that will one day demand release. Makak in several occasions emphasises that "his dream is not a dream," whereas others characterise it, "not only a dream, but a bad dream" (Walcott, Dream, 1970, p. 290).

Makak, an old black charcoal burner who comes to town, gets drunk, and is taken into prison by Corporal Lestrade, a mulatto guard who is the custodian of law and order during the later years of colonial power. In the dream scene of a mock trial, Lestrade accuses Makak of being drunk and damaging the premises of a local salesperson. However, in another dream sequence, Makak is crowned king in the romantic Africa of his root, surrounded by his wives, his warriors, and the masks of pagan gods (Dasht Peyma, 2009, p. 157).

Most critics agree that Derek Walcott's Dream on Monkey Mountain is a complex play, full of complicated, sometimes contradictory images and metaphors. Because of the text's richness, the play has attracted numerous interpretations of its many aspects. At the centre of numerous critics' reading of the play are Makak and the dream journeys he goes on that lead to self-discovery and his self-acceptance. "His journey to Africa," according to Dasht Peyma, "inspired by the apparition, and his escape into the forest are both imaginary journeys made in his mind. The dream journeys are symbolic; archetypal quests rooted in the ethnic history and collective consciousness of Caribbean people" (2009, p. 159).

It seems the dream in this play belongs both to Makak and to collective atmosphere of the whole plot. At the same time, as Makak's dream of Africa is displayed, he remembers a dream in which a white Goddess looks after him. However, he gives up this dream brutally beheading the woman with an African sword. This sacrifice expresses a sound reaction against a fantasy life alienated from reality.

\section{B. Dream on Monkey Mountain: A Christian Allegory in the Face of Colonisation}

Dream on Monkey Mountain, as Dasht Peyma states, "can be a political allegory of the state of the blacks in the postcolonial world in general and in the Caribbean in particular." The main character of the play, "Makak, is determined to go back to Africa as part of his vision" (2009, p. 158). Makak's journey, as Dasht Peyma believes, "involves some echoes of Christ (some kind of Messiah Figure-all throughout the play): Makak is compared to the Black Messiah who will lead the people of Africa and the African Diaspora to freedom" (2009, p. 159). In prison, two robbers follow him, and from Good Friday, he looks forwards "to the moment of resurrection on Easter Sunday." The prison can be a symbol of both "life and colonial rule" (2009, p. 159). Makak urges Moustique to leave everything behind and follow him; Makak heals the sick Josephus by urging him simply to believe and even Moustique tells the peasants that Makak "breathe resurrection" and he is "God's messenger" (Walcott, Dream, 1970, p. 251); "the wonder stories that people tell of Makak, and the doubt they encounter, are reminiscent of Gospel accounts; in the prison and in the escape to Monkey Mountain," Makak is "accompanied by two thieves, a Christ on the cross. Souris becomes a convert to Makak's faith, while Tigre remains outside, with his vision of souls tormented in hell" (Dasht Peyma, 2009, p. 159). 
Dream on Monkey Mountain "is set on an unnamed island in the West Indies at an unspecified time, assumed to be contemporary with the time the play was written. The play's action takes place in several locations, both real and imagined" (phantasmagorical narrative). The most real place is the prison run by Corporal Lestrade, where the play begins and ends. "Lestrade furiously defends the English law, but the law is used to abuse justice when he goes through a perfunctory justification of Makak's readiness to stand trial." In Makak's dream, the action goes from his hut on Monkey Mountain to a country road where he heals a sick man and then to the public marketplace before returning to the prison cell. After Makak, and two other black prisoners, Tigre and Souris (the two thieves in a supporting role like those by Christ's Crucifixion), escape, they spend time in the forest before going to a most unreal setting where Makak is a king. "All of these settings underline Makak's journey from a real existence that is harsh, through self-awareness, and back to a reality in which he functions as a better person" (Dasht Peyma, 2009, pp. 161-62).

Makak's situation in prison can be seen as a metaphor for the mental situation brought about by colonialism through Corporal Lestrade. "Makak has just been arrested for being drunk and smashing a local café while claiming he was the king of Africa." Tigre and Souris try to challenge the Corporal "as he does his duty." The Corporal grows irritated and compared them to "animals." Corporal Lestrade, who is a "mulatto, represents the complicity of certain elements of the black community with the colonisers, although he should be the ally of the other blacks" (Dasht Peyma, 2009, p. 162). He mocks three black prisoners:

CORPORAL. Animals, beasts, savages, cannibals, niggers, stop turning this place to a stinking zoo! (Walcott, Dream, 1970, p. 216)

He calls black people a tribe of apes:

CORPORAL. In the beginning was the ape, and the ape had no name, so God call him man. Now there were various tribes of the ape, it had gorilla, baboon, orang-outa, chimpanzee, the blue-arsed monkey and marmoset, and God looked at his handiwork, and saw that it was good. For some of the apes had straighten their backbone, and start walking upright, but there was one tribe unfortunately that lingered behind, and that was the nigger. Now if you apes will behave like gentlemen, who knows what could happen? (Walcott, Dream, 1970, pp. 216-17)

The whole passage is a parody of "Genesis," full of grammatical errors and misspellings. The Corporal asks Makak for basic information, but the prisoner only wants to go home. Lestrade mockingly asks him, "Where is your home? Africa?" The implication is that he has no homeland. It seems Walcott, through Makak, speaks about racial despair and the sense of complete loss of hope for his race. In "Ref. [7]",, Walcott links this feeling to being "rootless," having no connection with a tradition that gives one personal value, of having no home, of being a stranger in a home owned by someone else, by whites (1970, p. 21).

A mock trial conducted by the Corporal, where Tigre and Souris put on towels as "judge's robes and the Corporal defends Makak. The Corporal presents the facts of the case to the judges. He reveals that Makak claims to have had a dream in which he was told he was the direct descendant of African kings". The Corporal charges that Makak created a "disturbance in a public bar and that he spoke obscenely about a dream" he had and in which "he had spoken to a spirit" (Dasht Peyma, 2009, p. 163). In addition, Makak is charged with urging others to "join him in seduction and the defilement of the flag" (Walcott, Dream, 1970, p. 225). "The trial," as Dasht Peyma illustrates, "parodies Christ's appearance before Pontius Pilate, the governor of the Roman Judaea province, and therefore establishes Makak as some kind of Messiah figure" (2009, p. 163).

When Makak comes to make his deposition, his cage is flown out of sight, and as he tells his vision, its subject-white Goddess-appears and then withdraws. This is the dream which has caused him to go berserk and in his madness claim to be "the direct descendant of African kings, a healer of leprosy and the saviour of his race" (Walcott, Dream, 1970, p. 225).

In scene one, seeing his friend, Moustique, Makak says that he thinks he is going mad and asks Moustique how long they have known each other. Moustique tells him, "Three, four" years. Makak tells sceptical Moustique of his early morning encounter with the white Goddess, which he insists was not a dream. She amazed him by calling out his real name; a name he does not use.

MAKAK. Saddle my horse, if you love me, Moustique, and cut a sharp bamboo for me, and put me on that horse, for Makak will ride to the edge of world, Makak will walk like he used to in Africa, when his name was lion! (Walcott, Dream, 1970, p. 240)

In act one, scene two, "a group of women robed in white runs onstage, dancing and singing. They are followed by men carrying a sick man on a stretcher." Makak cures the apparently sick man by holding a hot coal in one hand and touching the man's head with the other. Coal in this metaphor can be racial blackness; it is one of the cheapest commodities in the marketplace. Charcoal burning is the work of those who can get nothing better. Then, the "pressure," is oppression. Yet through self-trust, coal can become "diamond" (Dasht Peyma, 2009, p. 165). When it seems that his efforts have failed, Makak blames self-hatred and lack of faith:

MAKAK. Let us go on compere. These niggers too tired to believe anything again. (Walcott, Dream, 1970, p. 250)

Makak's words recall his own answer, in the prologue, to Corporal Lestrade's question, "What is your race?": "I am tired." If the others are "trees without names," Makak also has forgotten his name and has been lost between the false identities of "Monkey" and "Lion." Makak is overwhelmed by the power he possesses now but Moustique's attitude is completely mercenary, "I see a sick man with snake bite and a set o' damn asses using old-time medicine. I see a road 
paved with silver" (Walcott, Dream, 1970, p. 250). From the beginning of scene one, Makak is accompanied by Moustique, like Don Quixote and Sancho Panza; however, this company reminds us of Christ and Peter, with his special greed in silver. Moustique's greed brings disaster. He impersonates Makak by appropriating Makak's vision to their own ends, and "he uses the language of Afrocentrism to get money from the people in the marketplace." However, "his betrayal of the vision is itself betrayed" (Dasht Peyma, 2009, p. 166), when he is recognised by Basil that he is not Makak, which in turn leads the people to reject the false prophet.

At the heart of Dream on Monkey Mountain there is "a search for and acceptance of one's identity. When Makak is questioned at the beginning of the play, he cannot tell Corporal Lestrade his real name or much about himself” (Dasht Peyma, 2009, p. 167).

In act two, scene two, Makak, Tigre and Souris arrive in the forest. Moustique explains:

MOUSTIQUE. When I was a little boy, living in darkness, I was so afraid, it was as if I was sinking, drowning in a grave and me and the darkness was the same, and God was like a big white man, a big white man I was afraid of. (Walcott, Dream, 1970, p. 290)

Souris being frightened in the darkness of forest explains:

SOURIS. And that is what they teach me since I small. To be black like coal, and to dream of milk. To love God, and obey the white man. (Walcott, Dream, 1970, p. 290)

The result is a strain and rupture in identity. When all value is associated with whiteness, blacks almost necessarily seek to repudiate blackness, which is impossible. In the moonlight, the Corporal meets Basil and is made to confess his sins:

CORPORAL. Too late have I loved thee, Africa of my mind ... I jeered thee because I hated half of myself, my eclipse. But now in the heart of the forest at the foot of Monkey Mountain ...I kiss your foot, O' Monkey Mountain. [He removes his clothes] I return to this earth, my mother... now I am myself. [Rises] Now I feel better. Now I see a new light. (Walcott, Dream, 1970, p. 299)

Corporal Lestrade, alienated from his black self by his service to the whites, seems for a while, "cured of that alienation when the others make him strip naked" (Dasht Peyma, 2009, p. 168). Makak tells him, "They rejected half of you. We accept all. Rise. Take off your boots!" (Walcott, Dream, 1970, p. 300) Makak welcomes the Corporal back to the life given him at birth. Tigre comes out and scoffs at the Corporal, saying that now he knows what it is like to be a "nigger," naked, vulnerable, and humiliated, an animal. Makak tries to get Tigre to stop. Makak confesses he is lost and has forgotten the way. He surrenders his dream of Africa and admits that he is lonely, lost, an old man again:

MAKAK. I was a king among shadows. Either the shadows were real, and I was no king, or it is my own kingliness that created the shadows... I am lonely, lost, an old man again... drunk and disorderly, beaten down by a Bible, and tired of looking up to heaven (Walcott, Dream, 1970, p. 304).

Makak is now only a "shadow", horrified by his new vision of his own people who wrangle among themselves, and disobey him, “O’ God, O’ Gods, why did you give me this burden?” (Walcott, Dream, 1970, p. 305)

In act two, scene three, the apex scene, the dream reaches its climax in parody and pantomime. The scene functions as a dream-within-the-dream. The Chorus introduces the scene as a collective fantasy, and "the tribe" seems to take on a communal African identity. As the Chorus sings and dances in his praise, Makak is placed upon his throne. As Makak says that he is only a shadow, he is glorified as the "inventor of history." Earlier in the play, Walcott mocks Caribbean mimicry of European standards; here he pokes fun at the back to Africa movement (Walcott, Dream, 1970, p. 219).

Makak wants to identify his Apparition, the white Goddess. However, the Corporal insists that she should be beheaded in a powerful passage, which summarises the injurious effects of European cultural conditioning, and suggests that its power is dependent on the colonised person's own complicity:

CORPORAL. She is the white light that paralysed your mind that led you into this confusion. It is you who created her, so kill her! Kill her! The law has spoken. (Walcott, Dream, 1970, p. 319)

Makak beheads her. In so doing, he drives out "the stranglehold which the European side of his heritage has on him." However, since the white Goddess "is responsible for his African dream, the beheading also involves repudiation" on Afrocentric cultural essentialism (Dasht Peyma, 2009, p. 171). Therefore, Makak rejects simultaneously the twin "bewitching" of Europe and Africa and tells, "Now, O' God, Now I am free" (Walcott, Dream, 1970, p. 320). Makak recovers his real name. He has been called Makak-Monkey- until now, but now he is not a colonial mimic, imitating European or supposed African modes of behavior. He says, "My name is Felix Hobain ... I believe in my God" (Walcott, Dream, 1970, p. 322). The final tone of Makak's experience is acceptance, but the Corporal's tune is still the same. The Corporal's last words are, "Here is a prison. Our life is a prison." However, Makak's last words are very different. The suggestion is that the coming to term with hybrid origin and identity is an issue of relevance for all Caribbean people.

The play ends with Felix Hobain's (Makak's) realisation:

MAKAK. Makak lives where he has always lived, in the dream of his people. Other men will come, other prophets will come, and they will be stoned, and mocked, and betrayed, but now this old hermit is going back home, back to the beginning, to the green beginning of this world. (Walcott, Dream, 1970, p. 326)

Makak's powerful passage clearly argues against a return to Africa. For Makak, home is the Caribbean land. It is viewed as "the green beginning of this world." 


\section{Dream on Monkey Mountain: An Exploration of Revolutionary Consciousness}

According to Lloyd Brown in his article, "Ref. [4]", in Walcott's Dream on Monkey Mountain "the quest for an African identity becomes an exploration of that revolutionary consciousness which is the subject of Black (revolutionary) theatre in America" (1993, p. 193).

Walcott's play, as Brown argues, is painstakingly explicit about his symbolic structure. "The overt emphasis of both the 'dream' title and the Narrative phantasmagoria is unmistakable" (1993, p. 193). So are the explicit statements of the author's "The play is a dream, one that exists as much in the given minds of its principal characters as in that of its writer, and as such, it is illogical, derivative, contradictory" (Walcott, Dream, 1970, p. 208).

From here, as Brown argues, “it is not difficult to accept the play's 'revolution' as a dream, a vision which symbolically projects the revolutionary potential of Makak." In other words, the play is "an analysis of whatever exists in the minds of the hero and his contemporaries-his messianic dream about a Back-to-Africa pilgrimage from the oppressive poverty of the Caribbean, [to] his obsessive ambivalence towards the White world" (1993, p. 193).

Conversely, the revolutionary "dream" or the visionary quest of Walcott's Makak, as Brown asserts, symbolically projects the "psychological realities of the Black man's relationship with both the White West and with the African past" (1993, p. 194). The play's action represents the fantasies which constitute Makak's dream-world and which are reenacted in his mind during his overnight imprisonment; he is a Black Messiah whose quest for an African identity (he plans to return to Africa) "is inspired by an 'Apparition' (an image of the White woman)." But Walcott does not allow us the luxury of viewing Makak's dream "as an isolated, individual fantasy, for we are a part of his dream." Meanwhile, our implication is dramatised by the manner in which the "spectators" within the play/dream are incorporated into Makak's visionary world; his cell-mates, Tigre and Souris, the jailor Corporal Lestrade, and Makak's partner, Moustique-they are all principal actors in Makak's "fantasies" because, "although they see him as a weak-headed old man, the dream also exists in their minds and implicitly, in the minds of the play's Black (theatre) audience" (Brown, 1993, p. 195).

In one sense, according to Brown, "our African dream and our revolutionary transcendentalism are a kind of escape" (1993, p. 195). On its most elemental, sexual level, Makak's dream of a white goddess/apparition compensates for the fact that he is ugly, sexually repulsive, and lonely. And beyond this, "his dream lifts him above the harshness of his everyday poverty; the vision of an African splendour compensates for the self-hate that is ingrained in the Black psyche in a White world" (1993, p. 195). As Makak himself summarises, "I have left death, failure, disappointment, despair in the wake of my dreams" (Walcott, Dream, 1970, p. 305). But the nature of Makak's dream also touches upon the "ambiguities and ironic self-conflicts of a Black revolutionary consciousness, for our revolutionary dreams are not merely forms of escape." They are also, "paradoxically, a psycho-existential affirmation of self, of Black selfhood. However, overly idealistic his revolutionary cause may be, and despite the romanticisation of his 'royal' African heritage, Makak affirms his human identity precisely because the capacity to dream has survived within him" (Brown, 1993, p. 195).

As we will see later, according to Jungian Individuation, at the end of the quest, a new self emerges. Before his vision Makak is "despised and self-hating, an impoverished hermit whose ugliness makes Monkey Mountain an appropriate habitat." But at the end of his dream Makak expresses a "triumphant sense of his own humanity which has been confirmed for us by his proven capacity for dream." So that when he is released from prison "the regaining of physical freedom is analogous to a birth, to revolutionary beginnings for Makak and his people" (Brown, 1993, p. 195).

MAKAK. ...I have been washed from shore to shore, as a tree in the ocean. The branches of my fingers, the roots of my feet, could grip nothing, but now, God, they have found ground. Let me be swallowed up in mist again, and let me be forgotten, so that when the mist open, men can look up, at some small clearing with a hut, with a small signal of smoke, and say, "Makak lives there. Makak lives where he has always lived, in the dream of his people." Other men will come, other prophets will come, and they will be stoned, and mocked, and betrayed, but now this old hermit is going back home, back to the beginning, to the green beginning of this world. (Walcott, Dream, 1970, p. 326)

In other words, as Brown continues, the romantic fantasies about an African "home" of royal lions act as a catalyst, enabling Makak and his people to come home to their human selves. "The dream-fantasy about revolution involves and confirms a very real revolutionising of self-perception." But this phantasmagorical/fantasy-reality paradox does not account for all the "ambiguities which Walcott attributes to Makak's dream and its revolutionary ethos" (Brown, 1993, p. 195). Since the very nature of Makak's vision highlights a certain tension of self-conflict in the development of a revolutionary consciousness. "His revolutionary Black awareness can only be fully developed once he recognises that the Apparition represents his continuing and subconscious allegiance to the White world which his rhetoric rejects" (Brown, 1993, p. 196). When Makak beheads the Apparition, the self-conflict ends, because in his words, he is now "free"-of White value systems and images which have stunted his Black self-awareness.

Then, Makak's dream, as Brown argues, is a "mirror which reflects the paradoxes in his emergent self-awareness. The full development of a Black revolutionary consciousness depends upon a frank recognition of the Whiteness within, and of the Black-White tensions which account for the Black man's notorious double-consciousness," (the awareness of being a split person, a dual self whose different parts are at dire odds with one another. In one person; therefore, we have two deeply divided tendencies), "but which ironically, also spark his perceptual revolution by forcing him to confront his self-contradictions" (Brown, 1993, p. 197). Having recognised his self-hate and Whiteness for what it is, 
then he must destroy it before he can progress from his initial ambiguities (Black rhetoric, White Apparition) to the unequivocal freedom of Black self-acceptance. This is the kind of progression that the Black American critic Larry Neal describes; the Black revolution is an internal violence, "the destruction of a weak spiritual self for a more perfect self. But it will be a necessary violence." It is the only thing that "will destroy the double-consciousness-the tension that is in the souls of the black folk" (Brown, 1993, p. 197). Makak is the dreamer whose visions are, in one sense, symbolical of that fantasy/escape which colours the prophetic ideal. However, in a more pressing sense these visions also imply the capacity to revolutionise self-perception. Hence, although the dreams themselves must end, this ending is actually a beginning - the existential beginning of a new Black self-definition.

\section{Dream on Monkey Mountain under the Light of Jungian Psychology and Its Archetypal Insights}

Carl Jung's foremost contribution to myth criticism is his "theory or racial memory and archetypes." In developing this concept, "Jung expanded Freud's theories of the personal unconscious, asserting that beneath this is a primeval, collective unconscious shared in the psychic inheritance of all members of the human family" (Guerin et al., 1985, p. 176). Just as certain instincts are inherited, "so more complex psychic predispositions (that is, a 'racial memory') are inherited by human beings" (Guerin et al., 1985, p. 176). Jung was also careful to explain that "archetypes are not inherited ideas or patterns of thought, but rather that they are predispositions to respond in similar ways to certain stimuli." He indicated further that "archetypes reveal themselves in the dreams of individuals, so that we might say that dreams are personalised myths and myths are depersonalised dreams" (Guerin et al., 1985, p. 177).

One major contribution is Jung's "theory of individuation as related to those archetypes designated as the shadow, the persona, and the anima. Individuation is a psychological 'growing up,' the process of discovering those aspects of one's self that make one an individual different from other members of his species." It is essentially a process of recognition - that is, as he matures, the individual must consciously recognise the various aspects, unfa vourable as well as favourable, of his total self. Jung theorises that neuroses (like madness in Makak's case) are the result of "the person's failure to confront and to accept some archetypal component of his unconscious" (Guerin et al., 1985, p. 179)

The shadow, persona, and anima are "structural components of the psyche that man has inherited. The shadow is the darker side of our unconscious self, the inferior and less pleasing aspects of the personality, which we wish to suppress" (Guerin et al., 1985, p. 180). The white Goddess, with her femme fetale seductions, is a classic representation of the devil figure designated by Jung as the shadow. She represents the dangerous aspect of the unrecognised dark half of Makak's personality, as well as his anima.

The anima is perhaps the most complex of Jung's archetypes. It is the "soul-image," in this sense; "anima is the contrasexaul part of man's psyche, the image of the opposite sex that he carries in both his personal and his collective unconscious. In other words, the human psyche is bisexual, though the psychological characteristics of the opposite sex in each of us are generally unconscious, revealing themselves only in dreams or in projections on someone in our environment" (Guerin et al., 1985, pp. 180-81). The persona is the "actor's mask that we show to the world-it is our social personality, a personality that is sometimes quite different from our true self." Jung explains that, "to achieve psychological maturity, the individual must have a flexible, viable persona that can be brought into harmonious relation with the other components of his psychic makeup." He states that an artificial or rigid persona results in such symptoms of neurotic disturbance as irritability and melancholy (Guerin et al., 1985, pp. 180-81).

"The literary relevance of Jung's theory of shadow, anima, and persona may be seen in our analysis" of Derek Walcott's play Dream on Monkey Mountain. In the first place, "Makak's persona is both false and inflexible." It is the social mask of a Messiah-figure, healing, self-righteous Christian-the persona of a prophet with all the connotations. In truth and reality, none of his miracles works. "His failure to recognise himself," when he confronts the white Goddess (his shadow), is merely another "indication of his spiritual immaturity." He has been stunted at first "in his psychological growth (individuation) because he is unable to confront his shadow," recognise it "as a part of his own psyche, and assimilate it to his consciousness." However, after the Corporal Lestrade (once here as the image of the Wise Old Man, albeit being incomplete) insists on beheading the white Goddess, Makak beheads her and restores his identity (Guerin et al., 1985, pp. 180-81).

The fundamental myth found in this play is "the Myth of Edenic Possibilities, which reflects the hope of creating a second Paradise, not in the next world and not outside time," (Guerin et al., 1985, p. 187), but in the Caribbean land, viewed as "the green beginning of this world" (Walcott, Dream, 1970, p. 326), "a place where man, after centuries of poverty, misery, and corruption, could have a second chance" to fulfil, in reality, "his mythic yearnings for a return to Paradise". Closely related to the Myth of Edenic Possibilities is the concept of the mythic New World hero (Adamic hero) who is described "as a radically new personality, the hero of the new adventure; an individual emancipated from history, happily bereft of ancestry, untouched and undefiled by the usual inheritances of family and race, an individual standing alone, self-reliant and self-propelling, ready to confront whatever awaited him with the aid of his own unique and inherent resources" (Guerin et al., 1985, p. 187).

Dream on Monkey Mountain is informed by several archetypal patterns and symbolic meanings encountered throughout world literature. These examples are by no means comprehensive, but represent some of the more common archetypal images that the reader is probably to face in literature. At the centre of numerous critics' reading of the play are Makak and the dream journeys he goes on that lead to self-discovery and his self-acceptance. "His journey to Africa," according to Dasht Peyma, "inspired by the Apparition, and his escape into the forest are both imaginary 
journeys made in his mind. The dream journeys are symbolic; archetypal quests rooted in the ethnic history and collective consciousness of Caribbean people" (2009, p. 159).

It seems the dream in this play belongs both to Makak and to collective atmosphere of the whole plot. At the same time, as Makak's dream of Africa is displayed, he remembers a dream in which a white Goddess looks after him. However, he gives up this dream brutally beheading the woman with an African sword. This sacrifice expresses a sound reaction against a fantasy life alienated from reality. Her beheading signifies the scapegoat sacrifice. Here the central motif with which Derek Walcott deals is the archetype of scapegoat. This motif centred in the belief that, by transferring the corruptions of the tribe to the white Goddess, "then by killing her (this scapegoat), the tribe could achieve the cleansing and atonement thought necessary for natural and spiritual rebirth. This blood sacrifice and purification were considered as a magical guarantee of rejuvenation, an insurance of life" (Guerin et al., 1985, p. 166).

Makak, demonstrating the features of a redeemer and a saviour, is a "mythic and microcosmic representation of the lives of West Indians and of the legacy of racial subjugation and poverty" (Dasht Peyma, 2009, p. 160). His journey, as Dasht Peyma believes, "involves some echoes of Christ: Makak is compared to the Black Messiah who will lead the people of Africa and the African Diaspora to freedom” (2009, p. 159). All this passage establishes Makak as some kind of Messiah figure.

In Makak's dream, "the action goes from his hut on Monkey Mountain to a country road where he heals a sick man and then to the public marketplace before returning to the prison cell." After Makak, and two other black prisoners, Tigre and Souris, escape, "they spend time in the forest" before going to a most unreal setting where Makak is a king. "All of these settings underline Makak's journey from a real existence that is harsh, through self-awareness, and back to a reality in which he functions as a better person" (Dasht Peyma, 2009, pp. 161-62). Makak's "dark quest leads him down the labyrinthine ways of the human mystery, the mystery of man's life and destiny" (identity). His quest is the quest undertaken by all of Caribbean people "who would gain that rare and elusive philosopher's stone, self-knowledge" (Dasht Peyma, 2009, pp. 161-62).

What we encounter noticeably here is the very common archetypal images of hero archetypes (archetypes of transformation and redemption). Through his quest, Makak, as a saviour or deliverer, undertakes an imaginary journey. Like Don Quixote, Makak is a wanderer, separated from his homeland, idealistically in search of a reality more substantial than that embraced by the ancestry society he has rejected. Forest signifies paradise; innocence; unspoiled beauty; and fertility. Due to his forest dream, a quest to restore his identity, Makak "undergoes a series of painful experiences in passing from ignorance and innocence into spiritual maturity (Guerin et al., 1985, p. 162); he comes to the age of a moral reborn-when he decides to behead the white Goddess to release himself and his nation. Makak's situation in prison can be seen as a metaphor for the mental situation brought about by colonialism through Corporal Lestrade. "Makak has just been arrested for being drunk and smashing a local café while claiming he was the king of Africa." As he tells his vision, its subject-white Goddess-appears and then withdraws. This is the dream which has caused him to go berserk and in his madness claim to be "the direct descendant of African kings, a healer of leprosy and the saviour of his race" (Walcott, Dream, 1970, p. 225).

Dream on Monkey Mountain is a play that explores "the various ways in which racism defines an unlivable identity for oppressed people, an identity that pushes towards madness" (Hogan, 2000, p. 45). Walcott, at various points, makes this theme explicit. For example, he draws the epigraph for part one from Sartre's prologue to "Ref. [10]": because of "always being insulted," the self becomes "dissociated, and the patient heads for madness" (Walcott, Dream, 1970, p. 211). On the other hand, as the mulatto Corporal Lestrade puts it in dialogue with Basil: "My mind, my mind. What's happened to my mind"? and Basil replies: "It was never yours, Lestrade" (Walcott, Dream, 1970, p. 297). His mind was never his own because it was always defined by the attributed categories of racism, because his identity was always a matter of what he was told he was. When Makak has a vision of the white Goddess in the prison, Lestrade says, "My Lord, is this rage for whiteness that does drive niggers mad" (Walcott, Dream, 1970, p. 228). A number of writers examined the ways in which oppressive ideologies undermine personal identity and even lead to madness. (Dasht Peyma, 2009, p. 158). Thus, much of the play explores the absolute valorisation of whiteness, and absolute devaluation of blackness in colonial racist ideology.

In act two, the scene three functions as a dream-within-the-dream. The Chorus introduces the scene as a collective fantasy, and "the tribe" seems to take on a communal African identity. As the Chorus sings and dances in his praise, Makak is placed upon his throne. As Makak says that he is only a shadow, he is glorified as the "inventor of history." Earlier in the play, Walcott mocks Caribbean mimicry of European standards; here he pokes fun at the back to Africa movement (Walcott, Dream, 1970, p. 219).

Makak wants to identify his Apparition, the white Goddess. However, the Corporal insists that she should be beheaded in a powerful passage, which summarises the injurious effects of European cultural conditioning, and suggests that its power is dependent on the colonised person's own complicity:

CORPORAL. She is the white light that paralysed your mind that led you into this confusion. It is you who created her, so kill her! Kill her! The law has spoken. (Walcott, Dream, 1970, p. 319)

The Corporal Lestrade, albeit providing incomplete pattern, here exemplifies the Jungian concept of the Wise Old Man who is "the custodian of law and order during the later years of colonial power. In the dream scene of a mock trial," Lestrade accuses Makak of being drunk and damaging the premises of a local salesperson. He provides the social 
guidance and moral wisdom for the old hero. The Corporal Lestrade insists that the white Goddess should be beheaded. This is the only remedy to emancipate Makak and his tribe. Makak beheads her. In so doing, he drives out "the stranglehold which the European side of his heritage has on him." However, since the white Goddess is "responsible for his African dream, the beheading also involves repudiation" on Afrocentric cultural essentialism (Dasht Peyma, 2009, p. 171). Therefore, Makak rejects simultaneously the twin 'bewitching” of Europe and Africa and tells, "Now, O' God, Now I am free" (Walcott, Dream, 1970, p. 320). Makak recovers his real name. He has been called Makak-Monkeyuntil now, but now he is not a colonial mimic, imitating European or supposed African modes of behavior. He says, "My name is Felix Hobain ... I believe in my God" (Walcott, Dream, 1970, p. 322). Her white colour (in its negative aspect) signifies death, horror, the supernatural, and the impairing truth of a baffling global mystery. In addition, the white Goddess represents the archetypal woman (femme fatale), associated with sensuality, fear, danger, darkness, and death; the unconscious in its terrifying aspects.

The final tone of Makak's experience is acceptance: the suggestion is that the coming to term with hybrid origin and identity is an issue of relevance for all Caribbean people. The play ends with Felix Hobain's (Makak's) realisation:

MAKAK. Makak lives where he has always lived, in the dream of his people. Other men will come, other prophets will come, and they will be stoned, and mocked, and betrayed, but now this old hermit is going back home, back to the beginning, to the green beginning of this world. (Walcott, Dream, 1970, p. 326)

Makak's powerful passage clearly argues against a return to Africa. For Makak, home is the Caribbean land. It is viewed as "the green beginning of this world." The green colour here (in its positive aspect) is an archetype and has a symbolic meaning signifying growth, sensation, hope, fertility and continuity.

\section{CONCLUSION}

When identifying different strands of criticism on Walcott's Dream on Monkey Mountain, one is pleasantly surprised by the scope of theoretical approaches towards his dramatic work. Almost every critical school of literary theory can be found in the writings on Walcott's theatre. This variety of critical approaches may be due to the fact that the scope of Walcott's works for the stage ranges from epic drama to musical. This diversity in form is paralleled by an even greater variety of content, making it all but impossible to tag Walcott's drama with a single label.

An investigation into the play from the perspective of the Jungian psychology could deepen our understanding of the orchestrating function of the collective unconscious and, more important, Derek Walcott's philosophical reflections on racial memory, dreams, and archetypes. Dream on Monkey Mountain is not only a dream but also a play, with an audience that participates in the dreaming. Makak's hallucinations, his people's hallucinations, become shared with the audience. The audience members complete the play as they participate in the collective delirium, collective dream, and potentially collective resistance, conveying the communal qualities of decolonisation.

As we considered, in Dream on Monkey Mountain, Makak was the dreamer whose visions were, in one sense, symbolical of that fantasy/escape which coloured his prophetic ideal (Dream on Monkey Mountain as a Christian Allegory in the Face of Colonisation). However, in a more pressing sense these visions also implied the capacity to revolutionise self-perception (Dream on Monkey Mountain as an Exploration of Revolutionary Consciousness). Hence, although the dreams themselves had to end, the ending was actually a beginning-the existential beginning of a new Black self-definition (Dream on Monkey Mountain under the Light of Jungian Psychology and its Archetypal Insights).

\section{References}

[1] Breslin, Paul. (2001). Nobody's Nation: Reading Derek Walcott. Chicago and London: University of Chicago Press.

[2] Brown, Lloyd. (1993). Dreamers and Slaves- The Ethos of Revolution in Walcott and Leroi Jones. In Robert D. Hamner (eds.), Critical Perspectives on Derek Walcott. Washington DC: Three Continents Press, 193-201.

[3] Dasht Peyma, Nasser. (2009). Postcolonial Drama: A Comparative Study of Wole Soyinka, Derek Walcott and Girish Karnad. New Delhi: Rawat Publications.

[4] Fanon, Frantz. (1968). The Wretched of the Earth, trans. Constance Farrington. Grove Press, Inc.,

[5] Fox, Robert E. (1993). Big Night Music: Derek Walcott's Dream on Monkey Mountain and the Splendours of Imagination. In Robert D. Hamner (eds.), Critical Perspectives on Derek Walcott. Washington DC: Three Continents Press, 202-211.

[6] Guerin, Wilfred L., et al. (1985). A Handbook of Critical Approaches to Literature. $2^{\text {nd }}$ Ed. New York, Hagerstown, Philadelphia, San Francisco, London: Harper \& Row Publishers.

[7] Hamner, Robert D. (1997). Critical Perspectives on Derek Walcott. ed. Washington DC: Three Continents Press.

[8] Haney II, William S. (2005). Hybridity and Visionary Experience: Derek Walcott's Dream on Monkey Mountain. Mystics Quarterly. Vol. 31, No. 3/4, 81-108.

[9] Hogan, Patrick Colm. (2000). Colonialism and Cultural Identity: Crises of Tradition in the Anglophone Literatures of India, Africa and the Caribbean. New York: Suny Press.

[10] Hogan, Patrick Colm. (1994). Mimeticism, Reactionary Nativism, and the Possibility of Postcolonial Identity in Derek Walcott's Dream on Monkey Mountain. Research in African Literatures. Indian University Press: Bloomington, Vol. 25, No. 2, $103-119$.

[11] Jones, Leroi and Larry Neal, Apollo. (1968). And Shine Swam On. In Baraka Amiri and Larry Neal (eds.), Black Fire: An Anthology of Afro-American Writing. New York: Morrow, 656. 
[12] Josephs, Kelly Baker. (2010). Dreams, Delirium, and Decolonisation in Derek Walcott's Dream on Monkey Mountain. New York: Small Axe: A Caribbean Journal of Criticism, Vol. 14, No. 2, 32.

[13] Jung, Carl. (1958). Psyche and Symbol. Garden City, New York: Doubleday.

[14] Schorer, Mark. (1946). William Blake: The Politics of Vision. New York: Holt, Rinehart and Winston.

[15] Thieme, John. (1999). Derek Walcott. Manchester: Manchester University Press.

[16] Walcott, Derek and William Baer. (1996). Conversations with Derek Walcott, eds. Jackson: University Press of Mississippi.

[17] Walcott, Derek. (1970). Dream on Monkey Mountain and Other Plays. New York: Farrar, Strause \& Giroux.

[18] Walcott, Derek and Philip Wheelwright. (1960). The Language of Poetry. Edited by Allen Tate. New York: Russell and Russell.

[19] Walcott, Derek. (1970). What the Twilight Says: An Overture. In Derek Walcott (eds.), Dream on Monkey Mountain and Other Plays. New York: Farrar, Strause \& Giroux.

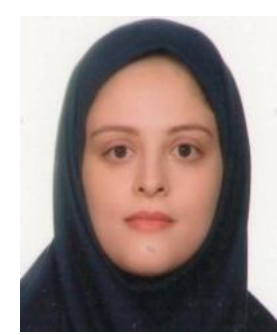

Zohreh Ramin (The Corresponding Author) is the assistant professor of English language and literature in Department of English in University of Tehran, Iran. She received her bachelor's degree in English language and literature from University of Isfahan in 1999, and both her master's degree and Ph.D. degree in the same major from University of Tehran in 2003 and 2011.

She is currently instructing in Tehran University. She has written a lot of articles some of which are listed here:

Shakespeare's Richard III and Macbeth: A Foucauldian Reading. (2013). Kata 15, No. 2, 20-35.

Revision of the American Frontier in Doctorow's Welcome to Hard Times. (2014). International Letters of Social and Humanistic Sciences 17, No. 2, 150-160.

E. L. Doctorow's World's Fair: The Political Power of Ventriloquism. (2017). The Explicator 75, No. 1, $25-27$.

Dr. Ramin, as an academician, is an active participant in various national and international seminars and symposiums. She has been supervising and advising a lot of theses and dissertations, along with holding and monitoring a lot of academic projects in Tehran University since she has graduated there.

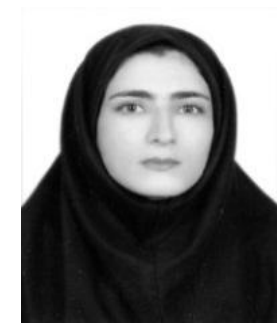

Monireh Arvin was born in Province Ahar, located in Tabriz, Iran. She received her bachelor's degree in English language and literature from Karaj Islamic Azad University; in 2005, and her master's degree in the same major from the same university in 2008. She is currently a Ph. D. Student of English literature in the department of English, in Alborz Campus, University of Tehran, Iran. Her research interests included literary criticism and post-modern studies.

She has worked as an English instructor at various universities including Parand Islamic Azad University, Karaj Islamic Azad University, etc. She is currently teaching English language and literature in Karaj Islamic Azad University and some language institutes. Meanwhile, she has majored in French language and she is teaching it in some language institutes. She has participated in numerous international and national conferences, and has written two books and a lot of articles some of which are listed here:

A Symbolic Deconstructed Colonialism in A Passage to India by E. M. Forster. (2015). Environment Conservation Journal, Uttarakhand, India. Vol. 16, No. Special Edition (SE), 223-229.

Reality versus Fantasy in William Dean Howells' Editha and Luigi Pirandello's War. (2015). Jurnal UMP Social Sciences and Technology Management, Malaysia. Vol. 3, No. 1, 803-808.

Socialism and the Possibility of Utopia in The Wesker Trilogy. (2016). Mediterranean Social Science Journal, Italy, Rome, Vol. 7, No. 3, S1, 296-302.

Dr. Arvin has obtained The Best Paper Reward in ICELL (November 16-17, 2016: 18th International Conference on English Literature and Linguistics.) Dubai, UAE for her paper "Frank Norris' McTeague: An Entropic Melodrama. 